\title{
COMMENTARY
}

\section{Treatment with recombinant human activated protein C: one size does not fit all}

\author{
Marcel Levi* \\ See related research by Shorr et al., http://ccforum.com/content/14/6/R229
}

\begin{abstract}
Protein C plays an important role in the coagulopathy associated with sepsis and probably also in the pathogenesis of sepsis-induced organ dysfunction. Plasma levels of protein C strongly correlate with clinical outcome in patients with severe sepsis. The RESPOND (Research Evaluating Serial Protein C Levels in Severe Sepsis Patients on Drotrecogin Alfa [Activated]) study shows that administration of recombinant human activated protein $C$ in patients with severe sepsis with alternative dose regimens adjusted to plasma levels of protein $C$ results in higher plasma levels of protein C. This may potentially translate to a better clinical outcome in patients with severe sepsis, although that was not directly shown in this trial.
\end{abstract}

Protein $\mathrm{C}$ is a physiological anticoagulant factor and has been implicated in the pathogenesis of sepsis for many years. In the previous issue of Critical Care, Shorr and colleagues [1] add to our knowledge of the role of protein $C$ in sepsis by presenting data from the RESPOND (Research Evaluating Serial Protein C Levels in Severe Sepsis Patients on Drotrecogin Alfa [Activated]) study, which demonstrates that administration of recombinant human activated protein $\mathrm{C}$ may modulate protein $\mathrm{C}$ levels and thereby potentially affect outcome in patients with severe sepsis. In $40 \%$ to $60 \%$ of patients with severe sepsis, plasma levels of protein $\mathrm{C}$ are low or very low because of impaired synthesis, consumption, and degradation by proteolytic enzymes, such as neutrophil elastase [2,3]. Several studies point to the fact that the plasma level of protein $\mathrm{C}$ may be regarded as a strong

\footnotetext{
*Correspondence: m.m.levi@amc.uva.nl

Department of Vascular Medicine and Internal Medicine, Academic Medical Center, University of Amsterdam, Meibergdreef 9, 1105 AZ Amsterdam, The Netherlands
}

predictor for the outcome in sepsis, and early improvement in protein $C$ levels strongly correlates with survival [4-6]. Apart from being a relevant biomarker, protein $C$ is likely to be involved in the pathogenesis of sepsis. The most typical example is meningococcal septicemia, in which very low plasma levels of protein $C$ play a pivotal role in the occurrence of purpura fulminans [7]. In addition, transgenic mice show that deficiency of protein $\mathrm{C}$ in sepsis is associated with enhanced inflammatory activity [8]. Also, restoration of low protein $\mathrm{C}$ levels in septic baboons resulted in an amelioration of coagulopathy and reduced mortality [9]. Hence, there is ample evidence that increasing protein $\mathrm{C}$ levels in patients with sepsis could significantly improve clinical outcome.

Shorr and colleagues show that the effect of variable dose regimens of recombinant human activated protein C can achieve this therapeutic goal. Patients who were randomly assigned to a strategy in which administration of recombinant human activated protein $C$ was adjusted to their endogenous protein $C$ levels - and who thereby sometimes received higher doses of recombinant human activated protein $\mathrm{C}$ (that is, 30 or $36 \mu \mathrm{g} / \mathrm{kg}$ per hour compared with the usual dose of $24 \mu \mathrm{g} / \mathrm{kg}$ per hour) and for a longer duration - achieved 7\% higher levels of protein $\mathrm{C}$ as compared with conventional treatment. Remarkably, the authors' results confirmed the finding that normalization of protein $C$ levels within 7 days had a major impact on mortality $(10.3 \%$ in patients with normalized protein $\mathrm{C}$ levels compared with $32.0 \%$ in patients who did not normalize).

One of the strengths of the study by Shorr and colleagues is that it is the first major clinical study investigating differential doses of recombinant human activated protein C. It is fair to say that dose-finding studies with recombinant human activated protein $\mathrm{C}$ are quite limited and that the currently used dose of $24 \mu \mathrm{g} / \mathrm{kg}$ per hour has been based on a plateau effect on D-dimer levels in a single phase II clinical trial [10]. It may well be that some patients with severe sepsis may need higher doses of activated protein $\mathrm{C}$ concentrate and for a duration longer than the standard 4-day schedule. The study by Shorr and colleagues demonstrates that this is 
not associated with an increase in major bleeding complications during the infusion period. As major bleeding is a concern in patients with severe sepsis and as recombinant human activated protein $\mathrm{C}$ has been shown to significantly (albeit, in absolute terms, very modestly) increase this risk [11], it is reassuring that the studied dose regimens in the RESPOND study did not clearly increase the bleeding rate.

Rather than intensifying or prolonging the treatment with activated protein $\mathrm{C}$, many clinicians have adopted the practice of terminating the administration of recombinant human activated protein $\mathrm{C}$ in patients who are admitted with severe sepsis but who demonstrate a rapid and significant improvement in their clinical condition. Although this seems to be a logical and costconscious measure, we need to realize that this practice is not supported by sound clinical trial data.

A limitation of the study by Shorr and colleagues is that focusing on zymogen protein $C$ levels may ignore the fact that, in patients with severe sepsis, protein $C$ activation may be markedly impaired. Indeed, a significant downregulation of thrombomodulin, caused by proinflammatory cytokines such as tumor necrosis factor-alpha and interleukin-1, may occur in patients with severe sepsis, resulting in diminished protein $\mathrm{C}$ activation $[2,12]$. It may well be that directly administering activated protein $\mathrm{C}$ will overcome this impaired activation and that plasma protein $\mathrm{C}$ levels will act as merely an easy-to-measure biomarker to guide this treatment. To further explore this issue, it would be interesting to perform a head-to-head comparison between administration of recombinant human activated protein $\mathrm{C}$ and zymogen protein $\mathrm{C}$ concentrate in patients with severe sepsis, looking at restoration of plasma levels of protein $\mathrm{C}$ but also at clinically relevant outcomes, such as organ dysfunction and mortality.

In conclusion, the RESPOND study shows that a differential approach to the administration of recombinant human activated protein $\mathrm{C}$ may result in a more effective normalization of protein $C$ levels. It is tempting to speculate on the translation of these findings to better treatment outcome in patients with severe sepsis, but we need additional clinical studies that would demonstrate such an effect. In the meantime, it is clear that, in regard to activated protein $C$ treatment in patients with sepsis, one size apparently does not fit all.

\section{Abbreviation}

RESPOND, Research Evaluating Serial Protein C Levels in Severe Sepsis Patients on Drotrecogin Alfa (Activated).

\section{Competing interests}

The author declares that he has no competing interests.

Published: 17 January 2011

\section{References}

1. Shorr AF, Janes J, Artigas A, Tenhunen J, Wyncoll D, Mercier E, Francois B, Vincent IL, Vangerow B, Heiselman DE, Leishman AG, Zhu YE, Reinhart K, for the RESPOND Investigators: Randomized trial evaluating serial protein $C$ levels in severe sepsis patients treated with variable doses of drotrecogin alfa (activated). Crit Care 2010, 14:R229.

2. Levi $\mathrm{M}$, van der Poll $\mathrm{T}$ : The role of natural anticoagulants in the pathogenesis and management of systemic activation of coagulation and inflammation in critically ill patients. Semin Thromb Hemost 2008, 34:459-468.

3. Anas A, Wiersinga WJ, de Vos AF, van der Poll T: Recent insights into the pathogenesis of bacterial sepsis. Neth J Med 2010, 68:157-162.

4. Brunkhorst F, Sakr Y, Hagel S, Reinhart K: Protein C concentrations correlate with organ dysfunction and predict outcome independent of the presence of sepsis. Anesthesiology 2007, 107:15-23.

5. Yan SB, Helterbrand JD, Hartman DL, Wright TJ, Bernard GR: Low levels of protein C are associated with poor outcome in severe sepsis. Chest 2001, 120:915-922.

6. Shorr AF, Bernard GR, Dhainaut JF, Russell JR, Macias WL, Nelson DR, Sundin DP: Protein C concentrations in severe sepsis: an early directional change in plasma levels predicts outcome. Crit Care 2006, 10:R92.

7. Fijnvandraat K, Derkx B, Peters M, Bijlmer R, Sturk A, Prins MH, van Deventer $\mathrm{SJ}$, ten Cate JW: Coagulation activation and tissue necrosis in meningococcal septic shock: severely reduced protein $\mathrm{C}$ levels predict a high mortality. Thromb Haemost 1995, 73:15-20.

8. Levi M, Dorffler-Melly J, Reitsma PH, Buller HR, Florquin S, van der Poll T, Carmeliet P: Aggravation of endotoxin-induced disseminated intravascular coagulation and cytokine activation in heterozygous protein $\mathrm{C}$ deficient mice. Blood 2003, 101:4823-4827.

9. Taylor FBJ, Chang A, Esmon CT, D'Angelo A, Vigano-D'Angelo S, Blick KE: Protein C prevents the coagulopathic and lethal effects of Escherichia coli infusion in the baboon. J Clin Invest 1987, 79:918-925.

10. Bernard GR, Ely EW, Wright TJ, Fraiz J, Stasek JE Jr., Russell JA, Mayers I, Rosenfeld BA, Morris PE, Yan SB, Helterbrand JD: Safety and dose relationship of recombinant human activated protein $C$ for coagulopathy in severe sepsis. Crit Care Med 2001, 29:2051-2059.

11. Levi MM, Eerenberg E, Lowenberg E, Kamphuisen PW: Bleeding in patients using new anticoagulants or antiplatelet agents: risk factors and management. Neth J Med 2010, 68:68-76.

12. Faust SN, Levin M, Harrison OB, Goldin RD, Lockhart MS, Kondaveeti S, Laszik Z, Esmon CT, Heyderman RS: Dysfunction of endothelial protein C activation in severe meningococcal sepsis. N Engl J Med 2001, 345:408-416.

doi:10.1186/cc9375

Cite this article as: Levi M: Treatment with recombinant human activated protein C: one size does not fit all. Critical Care 2011, 15:105. 